\title{
La docencia universitaria y la innovación educativa: los temas convocantes en dos congresos internacionales
}

\author{
Trombert, Alejandro R. ${ }^{1}$
}

\section{Resumen}

El presente comentario pretende dar cuenta de algunas de las temáticas vinculadas con la docencia universitaria que han sido desarrolladas en dos congresos internacionales llevados a cabo entre junio y julio de 2012. EI "VII Congreso Iberoamericano de Docencia Universitaria, Enseñanza Superior. Innovación y calidad en la docencia" tuvo lugar en la Facultad de Psicología y Ciencias de la Educación de la Universidad de Oporto, Portugal y el "VII Congreso Internacional de Docencia Universitaria e Innovación (CIDUI), La Universidad: una institución de la sociedad" se desarrolló en la Universidad Pompeu Fabra, Barcelona, España. Lejos de pretender cubrir exhaustivamente todas las temáticas que han sido objeto de reflexión y debate, el artículo intenta esbozar algunos tópicos que destacan en la agenda universitaria, tales como la innovación docente, los avances en la convergencia planteada por el Espacio Europeo de Educación Superior (EEES) a partir de la Declaración de Bolonia, el diseño curricular por competencias, el aprendizaje, la evaluación del aprendizaje, la evaluación de la calidad de la enseñanza, la formación del profesorado, la democratización de la enseñanza superior, la gestión organizacional y las políticas públicas en la Enseñanza Superior.

Palabras clave: docencia universitaria, innovación, calidad, aprendizaje, currículo por competencias

Presentado: 10-9-12 | Aceptado: 20-12-12

${ }^{1}$ Facultad de Bioquímica y Ciencias Biológicas UNL.

Ciudad Universitaria. Paraje El Pozo.

CP 3000. Santa Fe. Argentina

$0342-4541036$

atrombert@fbcb.unl.edu.ar 


\section{Sumary}

\section{University teaching and educational innovation: The issues organizers at two international conferences}

This contribution aim to remark some of the topics related to university teaching that have been developed in two international conferences held between June and July 2012. The "VII Iberoamerican Congress on University Teaching (CIDU), Higher Education. Innovation and quality in teaching" was held at the Faculty of Psychology and Educational Sciences of the University of Porto, Portugal and the "VII International Congress on University Teaching and Innovation (CIDUI), the University: an institution of society "was developed at the University Pompeu Fabra, Barcelona, Spain. Far from trying to comprehensively cover all the topics that have been the subject of discussion and debate, the article attempts to outline some topics of the university's agenda, such as teaching innovation, advances in the convergence process within the European Space for Higher Education (ESHE), the competency-based curriculum design, learning, learning assessment, evaluation of the quality of teaching, teacher education, democratization of higher education, organizational management and public policy in higher education.

Keywords: university teaching, innovation, quality, learning, competency curriculum. 